\title{
Redemption the Sin of Existence: The Reality and Reason in the Artistic Conception of Absurdity
}

\author{
DongXia Guan ${ }^{1}$ *
}

\author{
${ }^{1}$ Chengdu Neusoft University, Chengdu, China, 611844 \\ *Corresponding author. Email: 284432198@qq.com
}

\begin{abstract}
The drama Waiting for Godot expresses the embarrassing situation of human exsistance caused by the shattering of Westerners'faith on human rationality and the feelings of helplessness, absurdity, and confusion derived from it. Compared with the traditional western drama, it is obvious that Waiting for Godot is more openness. The inevitable attributes of waiting and the uncertainty of result constitute the dilemma of coexistence of absurdity and reality.In the absurdity, there is also the realistic nature of pursuing rational liberation, that is, hope in despair.Absurdity is a form, but reality is the essential state of human existence.It shows a world without time and repetition, or it is meant to show that nothing happens in human existence. Or, it shows the embarrassing situation of contemporary Westerners in the absurd world after losing their faith and metaphysical pursuit.
\end{abstract}

Keywords: Absurd drama, Human loneliness, Original sin, Spiritual dilemma

\section{THE SPIRITUAL DILEMMA OF BECKETT'S MODERN}

After experiencing two wars in the 20th century, in a world full of absurdity, absurd drama bravely faced the following facts:Those who believed that the world had lost its core meaning could no longer accept art forms based on invalidated standards and concepts.Beckett conveyed the absurdity born after the war to modern people in the artistic form of absurd theater.Associating the divine God with animal-like sounds seems to convey a message: human language has lost its communicative function, and thoughts have become meaningless, just like the dull sounds of animals.It seems that the boundary between human divinity and animality has been lost. Human beings are alienated and reduced to incomplete animals. Incompleteness and decay make human beings no longer have the power to manipulate their own existence and destiny.

Beckett also expresses the phenomenon of human alienation through the morbid attachment between people.For example, The pathological attachment between Pozo and the lucky guy is undoubtedly a typical representative of this phenomenon.Podro tied the lucky guy's neck with a rope, and drove him ahead with a whip like an animal.By making others a part of their own possessions, human beings have gained power that they could not have when they were an independent individual, but at the same time they have lost their independence.In fact, it is precisely because of the inability to get rid of personal loneliness that a symbiotic relationship is established with others. This is why the tyrannism and the masochism are always inseparably linked together.Beckett reveals the absurd dilemma of human existence in a dramatic way by showing various forms of alienation, such as animalization, deformity and psychosis of the characters[1].

In the two world wars, human society unreasonably used advanced science and technology to create weapons, causing millions of people to lose their lives. Rationality and science had brought political turmoil to the Western world, as well as economic depression and cruel wars, and moral decay for Westerners. The drama-Waiting for Godot expresses the embarrassing situation of human exsistance caused by the shattering of Westerners' faith on human rationality and the feelings of helplessness, absurdity, and confusion derived from it[2]. The crisis of faith and the collapse of the traditional value system have alienated the lives of the two wanderings in the playHango Ge and Di Di. They want to end this painful life, but they always subconsciously escape the end. There seems to be something preventing them from moving towards the final relief. There is still a trace of redemption 
in their hearts, and they are endlessly waiting for Godot's arrival.

\section{THE LOST 'GODOT’ MYTH}

Waiting and wandering are the eternal motifs of Western literature:Since Adam and Eve was expelled from the Garden of Eden, humans have begun to wander and wait.They were saved in the myth of Jesus conquering hell; In order to maintain the status of a hero and under the invasion of postmodern civilization, Odysseus's living environment has deteriorated to an extremely sad level. The splendid Garden of Eden has degenerated into a gloomy and dead wasteland; the tree of wisdom in the Garden of Eden has degenerated into an inexplicable withered tree, as if human wisdom has withered;Adam and Eve have lost their wisdom and rationality, and have become dysfunctional and ignorant tramps[3].Beckett used this anti-parallel mythological model to express the survival and mental state of Westerners in the 20th century:Mankind was abandoned by God in an endless, impending yellow field, waiting indefinitely for a vague hope called Godot to save mankind.But 'Godot' will not come after all, and 'waiting' has become a time-consuming and futile effort.Waiting, disappointed, waiting again, disappointed again, running out of life in anticipation, and savoring pain in disappointment, human beings are trapped in the endless predicament full of paradoxes of life and death, waiting and disillusionment. This is exactly the representation of modern humans who are hesitating in a dilemma[4].

The 'Godot' whose identity even Beckett cannot explain has given the play non-reality to a large extent.: It is definitely not showing the plot, but more like deducting one or a group of ideas-what this idea is. Who is Godot?Western critics have an explanation: Some people think that Godot is the God of Western Christianity, not only because Godot evolved from the word God, but also because Christian images appear repeatedly in the play_-The awe of Godot by Gogo and Didi are comparable to people's respect for God.(I think this statement is a bit far-fetched). Beckett said: If I knew who Godot was, I would have said it in the play.Godot may be a prolonged and seductive existence; Godot, as a symbol,may represent the hopeless expectation of the future of modern people living in panic.For Gogo and Di $\mathrm{Di}$, Godot is their long-awaited savior and hope. From the aesthetic point of view, the view that its theme is "revealing the awkward situation of human beings in an absurd universe" is to attribute the work to the ranks of absurd comics.On the surface, Waiting for Godot is indeed the absurdity and hopelessness of life expressed in absurd art form.But if we understand it this way, what is its meaning? In fact, its status in the Western world is very high.Wallend, a drama critic at the Swedish Academy, called it the 'first-rate work' in the world, and regarded it as the best portrayal of the alienation of the soul in the 'world on the rocks'[5].He also pointed out that none of Beckett's other works can compete with it in depth of thought.The reason for its high status is not only that it expresses the absurd consciousness of Westerners, but also that it has something that 'enjoys modern people from spiritual poverty.'This has to arouse our vigilance and rethink its deep connotation.

\section{REDEMPTION 'THE SIN OF EXISTENCE'}

In previous reviews, people often think that its theme is hopeless waiting, that is, 'revealing the awkward situation of human beings in an absurd universe', or expressing the absurdity and nihilism of life, and the meaninglessness of life.Ultimate care is a conscious pursuit of human life consciousness, and it is the most fundamental and exhaustive thinking and inquiry of human beings on the nature of self, the value of existence, and the meaning of life. From the myth of Sisyphus in ancient Greek mythology to Beckett's absurd drama Waiting for Godot, human beings have never stopped thinking about the tragic existence of self and the ultimate destiny.

The theory of original sin is a concept in Christian theology, meaning that one is born guilty.Because the first ancestors of mankind, Adam and Eve, did not obey God's admonitions in the Garden of Eden. They stole the forbidden fruit and committed a sin. Their offspring were born with sin.In Christian theology, 'original sin' and 'salvation' constitute a pair of the most basic dialectical categories. The theory of salvation has a strong sentiment and spiritualism. This metaphysical'original sin' constitutes the root of all evils in the real world. Through a mysterious genetic effect, Adam's descendants can not avoid this original sin. Only by relying on the equally deterministic God's grace or Christ's salvation, it can be completely eliminated.

'Waiting for Godot' embodies this 'original sin' consciousness.Estragon: Repent of our birth? The birth of a confessor implies that he is born with sin and embodies the consciousness of 'original sin'.Vladimir also said: Since our cruel fate has destined us to become the gang of evil, let's be their representative at least this time! In Waiting for Godot, why should two homeless men wait for Godot? [6]Do they have to wait for Godot? Beckett's family believes in Christianity. Living in such a family environment, he is bound to be influenced by Christianity.

'Waiting for Godot' embodies the Christian consciousness of 'original sin'. The real 'waiting' is the way to obtain salvation, and the arrival of Godot will also mean the completion of salvation.In Waiting for Godot, this kind of 'salvation' is realistic, and the result is that salvation is ultimately impossible, and human's 'sin of existence' cannot be freed in reality after all.Its theme is 
not only to reveal the 'awkward situation' of human beings in an absurd universe, or to express the absurdity and nihilism of life, and the meaninglessness of life, but it also contains the meaning of 'making modern people out of spiritual poverty'[7]. The things that are energized in the middle contain the call to the divine existence beyond Dasein and the reconstruction of meaning.

\section{WAITING FOR HOPE IN SURVIVAL REALITY}

Beckett believes that the existence and nonexistence of human beings are absurd. Life is a dream, and people's efforts are neither meaningful nor useful. Their works abandon the logic of the constitutional structure, the rational principles of character behavior and the accuracy of language. It only manages to solidify the absurdity of existence into a stage image, and only vividly express the ugly and dirty reality on the stage. .

Waiting for Godot broke the framework of traditional Western European drama. The plot, characters, and setting are very simple. The stage was empty, and there was only one bare withered tree beside the desolate road.Beckett uses an empty stage to show the desolation and indifference of the world, and expresses the absurdity and incomprehensibility of the world by the young leaves growing from bare trees overnight.Godot is also a symbol, indicating that humans desire to be saved. The process of waiting for Godot is a reflection of people's expectations for the future in panic.Drama is not the direct language of thought. Art is the kingdom of passion, not the realm of preaching.As long as the themes are to explain special political ideas, the scripts that express these themes will die with the disappearance of this ideology.Another reality of "Waiting for Godot" is that the dead tree grows a few tender leaves overnight. This is also a scene that can happen in nature.The tender leaves represent life and hope, and there is hope in life. This is the reality of Waiting for Godot-the dead tree grows tender leaves, and there is hope in despair.

Although from the myth of Sisyphus in ancient Greece to Beckett's absurd play 'Waiting for Godot', human beings have never stopped thinking about their own absurd existence and ultimate destiny, the real "absurdity" should exist in non-religious gods, nontranscendental subjective beliefs,non-metaphysical philosophy.

Beckett thinks about the existence of human beings from a philosophical or ultimate level. The essence of Estragon and Vladimir in the play should also be the essence of human beings. Waiting and disillusionment are a realistic description of the state of human existence. Absurdity is only a formal absurdity, and reality is the essential state of human existence[8].

\section{CONCLUSION}

Beckett's Waiting for Godot has no nostalgia for the gap, so there is no pain caused by nostalgia and pursuit.He understands that the fiction of language adorns events like 'snowing', and also gives meaning to many events, and also adorns the existence of people. Language conceals the meaning with a story.As a result, the fiction of language is always presented in Beckett's dramas in a faint way. He excludes readers from entering the nonexistent 'here' because the fictional characters and stories are all lies. Without a lie, people will no longer feel isolated when they return to reality.What he has to do in his drama is to weaken the language and let the reader become himself, without going back to the past from reality, nor creating expectations for the future in lies. The reader cannot be a role in the play. From beginning to end, they are just themselves.

\section{REFERENCES}

[1] Translated by Zhongxian Yu. Samuel Beckett's Works Collection 6: Waiting for Godot[M]. Changsha: Hunan Literature and Art Press,2013.

[2] Xiaojie Liu. The Absurd Drama from the Perspective of Existentialism - Take Waiting for Godot as an example [J]. Historical Monthly,2012(8).

[3] Zhiying Wang. Absurd drama, a form of expression of tragedy - Analysis of the tragedy color in "Waiting for Godot" [J]. The House of Drama, 2019 (11)

[4] Li Shaohua.The Implied Meaning of Samuel Beckett's Absurd Play "Endgame"[J],Cultural and educational materials.2011.20

[5] Ye Changhai. The similarities and similarities between narrative drama and absurd drama[J],Sichuan Opera,2011.4.

[6] Chen Yonghong. Analysis of "Waiting for Godot" reveals the tragedy of modern life[J],Hua Zhang,2011.17.

[7] Lan Renzhe. Feeling the Absurd Life and Witnessing Counter-Drama Techniques-The People and Their Situation in the "Waiting for Godot"[J].Foreign Literature Review,2004,(3).

[8] Song Xuezhi, Xu Jun.Translation and Research of French Dramas of the Absurd in China[J].Foreign Literature Studies, 2004,(2).doi:10.3969/j.issn.1003-7519.2004.02.025.

[9] Ran Dongping. Breaking through the artistic boundary of modernist drama-Comment on Samuel

Beckett's still drama [J]. Foreign Literature Review, 2003, (2). 